\title{
Lipid composition of lactational diets influences the fatty acid profile of the progeny before and after suckling
}

\author{
C. Lauridsen ${ }^{\dagger}$ and S. K. Jensen \\ Institute of Animal Health, Welfare and Nutrition, Faculty of Agricultural Sciences, Aarhus University, Research Centre Foulum, PO Box 50, DK-8830 Tjele, \\ Denmark
}

(Received 4 January 2007; Accepted 14 May 2007)

\begin{abstract}
The purpose of the present study was to compare the influence of adding no or $8 \%$ fat of varying sources (coconut oil, fish oil, rapeseed oil and sunflower oil) to diets for sows 1 week prior to farrowing and during lactation on the composition of fatty acids in plasma and tissues of the progeny while sucking and 3 weeks after weaning from the sow. A control diet without supplemental fat and four diets supplemented with $8 \%$ of coconut oil, rapeseed oil, fish oil or sunflower oil were provided to lactating sows $(\mathrm{n}=15)$, and during the post-weaning period the same weaner diet was provided to all piglets ( $\mathrm{n}=15$ litters), which were housed litterwise. The dietary ratio of n-6:n-3 fatty acids of the maternal diets largely influenced the progeny, as the ratio varying from 1.2 (fish oil) to 12.2 (sunflower oil) in the sow milk was reflected in plasma and adipose tissues of the sucking progeny. The liver showed similar variations according to dietary treatments, but a lower $n-6: n-3$ fatty acids ratio. From day 4 to later on during the suckling period, the concentration of C14:0, C16:0 and C18:1 in the liver of the piglets decreased, irrespective of the dietary treatments of sows. In plasma and liver, the total concentration of saturated fatty acids (SAFA), monounsaturated fatty acids (MUFA) and polyunsaturated fatty acids (PUFA) did not differ markedly in piglets sucking sows fed different dietary fatty acids, whereas the adipose tissue of piglets sucking sows fed sunflower oil and coconut oil showed the highest proportion of PUFA and SAFA, respectively. Weaning lowered the concentration of lipid-soluble extracts in plasma and the concentration of fatty acids in the liver of the piglets. Within the post-weaning period, dietary treatments of sows, rather than age of piglets, influenced the fatty acid composition of plasma and adipose tissue of the piglets, whereas the hepatic fatty acid profile was more affected by the age of the piglets during the post-weaning period. This study shows that the fatty acid profile of plasma and tissues of the progeny is highly dependent on the maternal dietary composition, and that the dietary impact persists for up to 3 weeks after the suckling period.
\end{abstract}

Keywords: dietary fat, fatty acids, weaning

\section{Introduction}

Nutrients are supplied to the newborn through the milk, and fat is particularly important not only for energy but also for supplying specific fatty acids thought necessary for optimal organ development. The pig is a good model for the human in terms of digestion, absorption and metabolism of milk lipids (Innis, 1993). The fatty acid composition of sow milk is easily influenced by the dietary fat source provided to the sow (Lauridsen and Danielsen, 2004), but little is known regarding the transfer of fatty acids from the milk to the progeny. The importance of providing adequate amounts of essential $n-6$ and $n-3$ fatty acids is well recognised. Studies of non-human primates and newborn

${ }^{\dagger}$ E-mail: Charlotte.lauridsen@agrsci.dk infants have shown that docosahexanoic acid (DHA) is essential to the normal functional development of the retina and the brain, especially in premature babies (Simopoulus, 1986). Deficiency of $n-6$ and/or $n-3$ fatty acids in developing infants can lead to deficiency symptoms, and may have implications for normal central nervous system development (Innis, 1992). However, besides the n-6 and n-3 fatty acids, the content of saturated fatty acids (SAFA) and unsaturated fatty acids (UFA) in infant diets is important in achieving appropriate compositions in developing tissue lipids.

One aspect is the transfer of fatty acids to the infant while sucking and the other aspect is the persistence of the fatty acids in the body tissues after the sucking period. The accessibility of fatty acids to the infant depends on their presence in the diet as well as the efficiency of fat digestion and absorption. The apparent digestibility of fat by sucking 
piglets is high (96\%; Cranwell and Moughan, 1989) but at weaning it decreases to $65 \%$ to $80 \%$ (Cera et al., 1988). The hypothesis of this study was that the fatty acid composition of the maternal diet would influence the transfer of fatty acids to the plasma and tissue of the progeny, and that this effect would persist after weaning from the mother. The purpose of the present study was therefore to compare the temporal influence of adding no or $8 \%$ fat of varying sources (coconut oil, fish oil, rapeseed oil and sunflower oil) to diets of sows 1 week prior to farrowing and during lactation on the composition of fatty acids in plasma and tissues of the progeny while sucking and 3 weeks after weaning from the sow.

\section{Material and methods}

\section{Animals}

At day 108 of gestation, 15 sows (alternate Danish Landrace $\times$ Danish Yorkshire) were randomly selected from the herd at the Danish Institute of Agricultural Sciences, and were assigned to one of five dietary treatments. The sows were arranged in a randomised complete-block design with three blocks (=parity 2, 3 and 4), and five sows per block, corresponding to five treatments per block. Within each block/parity, sows had a sire of the same breed, and were mated with a boar of the Duroc breed. Sows with piglets were housed individually in pens $(2.2 \times 2.4 \mathrm{~m})$ with a partly slatted floor, partly solid concrete combined with slats of iron grates. Sows and piglets were provided moderate quantities of straw bedding. Sows farrowed in crates were of $2.4 \mathrm{~m}$ length and flexible in width $(0.6$ to $0.8 \mathrm{~m})$. The creep area for piglets $(1.0 \times 1.3 \mathrm{~m})$ was partly covered, and heating lamps were installed during the 1st week after birth. After weaning, piglets within a litter were housed in $1.5 \times 1.8 \mathrm{~m}$ pens. The floor comprised two parts: a concrete, heated floor (located just behind the trough) and a manure area with a plastic net. The experiment complied with the guidelines of the Danish Ministry of Justice with respect to animal experimentation and care of animals under study.

\section{Diets and chemical analyses}

The experimental feed was provided to the sows from day 108 of gestation and until weaning (4 weeks after farrowing). The sow diets (Table 1) were based on soya-bean meal, barley and wheat. Diet 1 was the basal diet without addition of fat and diets 2 to 5 were formulated with $8 \%$ of rapeseed oil, fish oil, coconut oil and sunflower oil, respectively. The experimental diets were mixed at the Research Centre Foulum and provided as pellets. The diets were formulated in order to supply an equal amount of digestible essential amino acids per MJ net energy (NE).

The content of dry matter (DM), crude protein, crude fat and ash in the diets was determined according to the Association of Official Analytical Chemists (1990) procedures, and the crude fibre content and the enzyme digestibility of organic matter (EDOM) were analysed after the
Table 1 Composition of diets for sows (control (diet 1) and diets 2 to 5 (inclusion of $8 \%$ fat of different sources)) and for piglets ${ }^{t}$

\begin{tabular}{|c|c|c|c|}
\hline & Diet 1 & Diets 2 to 5 & Piglet diet \\
\hline \multicolumn{4}{|l|}{ Ingredients (\%) } \\
\hline Barley & 39.7 & 32.9 & 31.2 \\
\hline Wheat & 39.7 & 33.0 & 31.2 \\
\hline Soya-bean meal & 18.0 & 23.0 & 21.7 \\
\hline Calcium carbonate & 1.0 & 0.9 & 0.92 \\
\hline Fat & 0 & 8.0 & 5 \\
\hline Monocalcium phosphate & 1.1 & 1.7 & 0.91 \\
\hline Sodium chloride & 0.3 & 0.3 & 0.29 \\
\hline Fish meal, low in ash & - & - & 8.0 \\
\hline L-Lysine $^{\ddagger}$ & - & - & 0.39 \\
\hline DL-Methionine ${ }^{\ddagger}$ & - & - & 0.04 \\
\hline Minerals and vitamins ${ }^{\S}$ & 0.2 & 0.2 & 0.4 \\
\hline
\end{tabular}

'Diets 2 to 5 were included the following sources: diet 2: coconut oil, diet 3: rapeseed oil, diet 4: fish oil, diet 5: sunflower oil, and to the piglet diet was added animal fat.

${ }^{\ddagger} \mathrm{L}$-Lysine was added as a mix, which contained $40 \mathrm{~g}$ of L-lysine $\cdot \mathrm{HCl}, 50 \mathrm{~g}$ of $\mathrm{CaCO}_{3}$ and $10 \mathrm{~g}$ of $\mathrm{H}_{2} \mathrm{O}$. DL-Methionine was added as a mix, which contained $40 \mathrm{~g}$ of DL-methionine, $15 \mathrm{~g}$ of wheat bran, $35 \mathrm{~g}$ of $\mathrm{CaCO}_{3}$, and $10 \mathrm{~g}$ of $\mathrm{H}_{2} \mathrm{O}$.

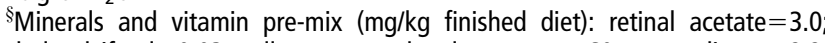
cholecalciferol $=0.03 ;$ all-rac- $\alpha$-tocopheryl acetate $=60 ;$ menadione $=2.2$; thiamin $=2.2$; riboflavin $=5.5$, pyridoxine $=3.3$; D-pantothenic acid $=16.5$; niacin $=22 \mathrm{mg} ;$ folic acid $=1.65 ;$ biotin $=0.22 ;$ cyanocobalamin $=0.22$; $\mathrm{BHT}=60, \mathrm{Fe}=100 ; \mathrm{Zn}=150 ; \mathrm{Mn}=28 ; \mathrm{Cu}=20 ; \mathrm{I}=0.3 ; \mathrm{Se}=0.3$.

methods of Aaman and Hesselman (1984) and that of Boisen and Fernandez (1997), respectively. Dietary lipids were extracted by the method of Stoldt (1952) using petroleum ether, and the long-chain fatty acids $(>\mathrm{C} 8)$ were determined by GLC (capillary) after saponification and methylation, as described by Rothenberg and Andersen (1980), with substitution of hexane with heptane and with C17:0 as the internal standard. The vitamin E ( $\alpha$-tocopherol) content of the diets was analysed by HPLC after saponification and extraction into heptane as described by Jensen et al. (1999).

Sows were fed twice daily and had access to water ad libitum. From day 108 to day 111 of pregnancy, daily rations of 25.5 MJ NE were given. Around farrowing, 19.3 MJ NE per day was provided, followed by 23.2 to $27.0 \mathrm{MJ} \mathrm{NE}$ on days 2 and 3 post farrowing. Thereafter, feed was offered daily, adjusted to the intake of the individual sow (animals were fed to meet their desired daily intake but could empty the trough between feedings).

No creep feed was given to the piglets during the suckling period. After weaning (day 28 of age), all piglets had free access to a weaner diet, which was fed until 49 days of age (end of experiment). This weaner diet was a standard pelleted diet and the chemical composition was determined as described above for the sow feed.

\section{Recordings and analytical procedures}

Milk samples from each sow were obtained at days 4,18 and 25 of lactation by hand-milking from the teats (samples 
of teats were pooled) after injection of oxytocin. Milk samples were stored at $-20^{\circ} \mathrm{C}$ until analysis of fatty acid content and composition. Prior to analysis, milk samples were thawed and gently mixed in a water bath held at $40^{\circ} \mathrm{C}$. Fat was extracted from the milk according to the method of Bligh and Dyer (1959). To $500 \mathrm{mg}$ milk was added $0.50 \mathrm{ml}$ water, $1.00 \mathrm{ml}$ chloroform with $5.000 \mathrm{mg}$ C17:0 as internal standard and $2.00 \mathrm{ml}$ methanol. This monophasic mixture was shaken for $1 \mathrm{~min}$, then $1.00 \mathrm{ml}$ water and $2.00 \mathrm{ml}$ chloroform were added, and the mixture was shaken again for $1 \mathrm{~min}$, after which the mixture was centrifuged for $10 \mathrm{~min}$ at $1000 \times \mathbf{g}$ and exactly $1.00 \mathrm{ml}$ of the lower (chloroform) phase was taken out and trans esterified into fatty acid methyl esters after saponification with $\mathrm{NaOH}$ and esterified with boron trifluoride methanol complex and separated by GLC as described by Rothenberg and Andersen (1980).

Recordings of performance of the litters involved weekly registration of the individual piglet weight throughout the experimental period (days 0 to 49 of age) and of feed intake during the post-weaning period.

Blood samples of three piglets per litter were obtained from vena jugularis by puncture into heparinised vacuum tubes at days $4,18,25,35,42$ and 49 after birth. After centrifugation at $1000 \times \mathbf{g}$ for $10 \mathrm{~min}$ at $4^{\circ} \mathrm{C}$, the plasma samples were stored at $-80^{\circ} \mathrm{C}$ until analysis. On the same days, one piglet per litter was killed by intravenous injection of pentobarbital. After bleeding of the animals, samples of the liver and adipose tissue from the area around the hip muscle were obtained. Tissue samples were stored at $-20^{\circ} \mathrm{C}$ until analysis.

Determination of free fatty acids (FFA) in plasma was performed using the acyl-CoA synthase-acyl CoA oxidase (ACS-ACOD) method as prepared by Waco Chemicals USA, Inc. Concentrations and proportions of reagents were, however, slightly modified to optimise our specific analytical conditions. Analysis of free glycerol was based on the enzymatic conversion of glycerol to G-3-P and further oxidation to di-OH-acetone-P and hydrogen peroxide. The latter develops with 4-aminoantipyrine and chloropherol, which is a quinonemine dye detectable at $500 \mathrm{~nm}$ absorbance. Basic principles in the process are described by Fossati and Prencipe (1982) and Trinder (1969). Analyses of the plasma concentration of triglycerides (TG) were based on enzymatic determination of free glycerol after liberation from triglyceride using lipoprotein lipase. The analyses consequently do not differentiate between mono-, di- or triglyceride origin. The method is standardised by Technicon RA $^{\circledR}$ Systems (Tarrytown, NY, NY, USA). Plasma total cholesterol (CHOL) was determined after hydrolyses of cholesterol esters using cholesterol esterase. The free cholesterol in the presence of oxygen and cholesterol oxidase produces hydrogen peroxide, which in turn forms a quinoneimine dye, which is determined colormetrically at $500 \mathrm{~nm}$. Blood plasma glucose was analysed using an autoanalyser, ADVIA $1650^{\circledR}$ Chemistry System (Bayer Corporation, Tarrytown, NY, USA). Intra-assay variation (CV \%), inter-assay variation (CV \%) and relative bias (\% deviation from ideal value) were below the following values: 1.5,2.0 and 1.5, respectively). Analysis of triglyceride, $\mathrm{CHOL}$, glucose and free glycerol were all performed using an autoanalyser, OpeRATM Chemistry System, (Bayer Corporation, Tarrytown, NY, USA).

Concentration of fatty acids in plasma and liver was analysed according to Bligh and Dyer (1959) as described above with the following changes. One millilitre of plasma was used instead of $500 \mathrm{mg}$ milk and the addition of $0.500 \mathrm{ml}$ water was excluded. Liver samples $(3.00 \mathrm{~g})$ were homogenised in methanol $(6.00 \mathrm{~g}=7.6 \mathrm{ml})$, while being kept on ice. From this homogenate, $0.60 \mathrm{~g}$ was weighed out, and water, methanol, chloroform and internal standard were added as described above. Adipose tissue was solubilised in heptane in a water bath held at $80^{\circ} \mathrm{C}$ for $2 \mathrm{~h}$ and methylated directly and the fatty acid methyl esters were quantified as described above for feed (Rothenberg and Andersen, 1980).

\section{Statistical analysis}

Statistical analysis of data was accomplished using the MIXED procedure of Statistical Analysis Systems Institute (1999). Analyses of data obtained on the piglets were based on the following model:

$$
Y_{(i)}=\mu+a_{\mathrm{FS}(i)}+\beta_{\mathrm{D}(i)}+\gamma_{\mathrm{FS} \times \mathrm{D}(i)}+U_{\mathrm{SOW}(i)}+\varepsilon_{(i)},
$$

in which $Y_{(1)}$ is the dependent variable, $\mu$ the overall mean, $\alpha_{\mathrm{FS}(1)}$ the systematic effect of fat source, $\beta_{\mathrm{D}())}$ is the systematic effect of the day of sampling and $\alpha_{\mathrm{FS} \times \mathrm{D}(1)}$ the systematic effect of interaction between fat source and day. $U_{\text {sow(i) }}$ refers to the effect of sow/block (i.e. dependency between sow and block) and $\varepsilon_{(1)}$ denotes the error term. The sow or litter was considered as the experimental unit. The results of the statistical analysis are expressed as leastsquare means and s.e.

\section{Results}

\section{Analyses of feed}

Analysis of the experimental diets is presented in Table 2. From this table it can be observed that the natural content of fat provided with the feed ingredients was $2.8 \%$ of DM (control diets). Addition of $8 \%$ fat to the diets provided diets with crude fat ranging from $7.9 \%$ (coconut oil diet) up to $10.3 \%$ (rapeseed oil). By analysis of the crude fat content of the added fat sources, it was observed that the fat content of coconut oil was only $81 \%$, whereas the other fat sources had a content of fat above $97 \%$. No explanation for the lower fat content of the coconut oil was available to the authors. In general, analysis of the fatty acid composition of the experimental diets supplemented with fat reflected the fatty acid composition of the added fat source. With regard to the weaner diet, C18:1 was present in the greatest percentage, followed by $\mathrm{C} 16: 0$ and $\mathrm{C} 18: 2$. 
Table 2 Mean analysed chemical composition of diets

\begin{tabular}{|c|c|c|c|c|c|c|}
\hline \multirow[b]{2}{*}{ Fat source included } & \multicolumn{5}{|c|}{ Sow diets } & \multirow{2}{*}{$\begin{array}{l}\text { Piglet diet } \\
\text { Animal fat }\end{array}$} \\
\hline & - & Coconut oil & Rapeseed oil & Fish oil & Sunflower oil & \\
\hline DM (\%) & 87.8 & 86.5 & 88.0 & 88.7 & 86.8 & 89.4 \\
\hline Crude protein (\% of DM) & 19.2 & 20.3 & 20.0 & 19.8 & 20.1 & 24.3 \\
\hline Crude fat (\% of DM) & 2.8 & 7.9 & 10.3 & 9.8 & 9.1 & 9.3 \\
\hline Ash (\% of DM) & 5.3 & 5.9 & 5.8 & 5.9 & 5.8 & 5.87 \\
\hline Crude fibre (\% of DM) & 4.2 & 4.2 & 4.2 & 4.2 & 4.1 & 4.1 \\
\hline $\mathrm{EDOM}^{+}$ & 88.8 & 89.8 & 89.6 & 89.5 & 89.7 & 89.5 \\
\hline Net energy (MJ/kg DM) & 9.3 & 10.2 & 10.4 & 10.3 & 10.3 & 10.4 \\
\hline$\alpha$-Tocopherol (mg/kg feed) & 60.8 & 48.8 & 65.3 & 62.3 & 61.1 & 103 \\
\hline \multicolumn{7}{|l|}{ Fatty acids $(\mathrm{g} / \mathrm{kg} \mathrm{DM})^{\ddagger}$} \\
\hline No. of feed samples & 5 & 5 & 6 & 5 & 4 & \\
\hline $\mathrm{C} 8: 0$ & - & 0.21 & - & - & - & \\
\hline $\mathrm{C} 10: 0$ & - & 0.57 & 0.09 & 0.08 & 0.08 & $<0.01$ \\
\hline $\mathrm{C} 12: 0$ & 0.17 & 18.1 & 0.83 & 0.72 & 0.64 & 0.01 \\
\hline $\mathrm{C} 14: 0$ & 0.12 & 11.4 & 0.59 & 3.5 & 0.40 & 0.17 \\
\hline C16:0 & 4.5 & 13.6 & 9.4 & 16.4 & 10.9 & 1.83 \\
\hline C16:1 & 0.10 & 0.37 & 0.35 & 3.0 & 0.15 & 0.20 \\
\hline C18:0 & 0.71 & 3.3 & 2.1 & 2.3 & 3.8 & 0.96 \\
\hline C18:1 & 4.0 & 12.3 & 47.4 & 16.5 & 18.8 & 2.48 \\
\hline C18:2 & 11.9 & 14.1 & 27.4 & 13.2 & 53.3 & 1.41 \\
\hline C18:3n-3 & 1.2 & 1.4 & 7.7 & 2.2 & 2.1 & 0.17 \\
\hline$C 18: 3 n-6$ & - & - & - & 0.01 & - & $<0.01$ \\
\hline C18:4 & - & & & 1.5 & & 0.03 \\
\hline$C 20: 0$ & 0.06 & 0.13 & 0.47 & 0.18 & 0.42 & 0.02 \\
\hline C20:1 & 0.19 & 0.20 & 1.2 & 3.6 & 0.26 & 0.16 \\
\hline$C 20: 2$ & - & - & 0.09 & 0.26 & - & 0.02 \\
\hline$C 20: 3$ & - & - & - & 0.11 & - & - \\
\hline$C 22: 1$ & - & - & 0.36 & 5.0 & - & 0.14 \\
\hline$C 22: 0$ & 0.10 & 0.10 & 0.35 & 0.27 & 0.63 & - \\
\hline C24:0 & - & - & 0.17 & & - & - \\
\hline$C 20: 4$ & - & - & - & 0.26 & - & 0.02 \\
\hline$C 20: 5 n-3$ & - & - & - & 4.4 & - & 0.13 \\
\hline$C 22: 5 n-3$ & - & - & - & 0.56 & - & - \\
\hline$C 22: 6 n-3$ & - & - & - & 7.1 & - & 0.20 \\
\hline
\end{tabular}

Abbreviations are $\mathrm{DM}=$ dry matter.

${ }^{\dagger} \mathrm{EDOM}=$ enzyme digestibility of organic matter (Boisen and Fernandez, 1997).

${ }^{*}$ Content of selected fatty acids (if number of samples where the given fatty acid is presented is more than 2 ).

Fatty acid composition of the milk

The fatty acid composition of the sows' milk was influenced by the dietary fat source and the day of lactation (Table 3). Sunflower oil provided a high amount of $\mathrm{C} 18: 2$, and the polyunsaturated fatty acids (PUFA) C20:5, C22:5n-3 and C22:6 were mostly present in milk of fish oil-fed sows. Milk of sows provided with rapeseed oil showed the highest content of C18:1, and milk of sows fed coconut oil had a high content of C12:0. Dietary treatments had major impact on the ratio of $n-6: n-3$ fatty acids in the sow milk, e.g. ranging from 15.5 (sunflower oil) to 0.91 (fish oil). The lactation stage seemed to influence the content of fatty acids in the milk as the concentration of C18:0, C18:1, C20:1, C20:2, C20:3n-6, C20:4n-6 and MUFA was higher at day 4 of lactation compared with later on during lactation although this picture was not as clear for the sows on rapeseed oil.
Piglet responses during suckling

The average piglet weight gain from birth to weaning was not influenced by the dietary treatments of sows, and ranged between $5.00 \mathrm{~kg}$ (control diet) to $6.94 \mathrm{~kg}$ (sunflower oil) (s.e. $=0.63 \mathrm{~kg}$ ).

During the suckling period, the dietary treatment of sows, rather than age of piglets, influenced the fatty acid composition of plasma (Table 4). However, the total concentration of SAFA, MUFA and PUFA did not differ markedly in plasma of piglets sucking sows fed different dietary fatty acids. The ratio between $n-6$ and $n-3$ was highly influenced $(P<0.001)$ and reflected the ratio obtained in milk, e.g. ranging from 1.3 (fish oil) to 13.0 (sunflower oil). No effect was observed with regard to the age of piglets (Table 4), except on the concentration of C18:1 $(P=0.019)$, which decreased as the age progressed (from $1.61 \mathrm{mg} / \mathrm{g}$ (day 4) $1.10 \mathrm{mg} / \mathrm{g}$ (day 25)). 
Lauridsen and Jensen

Table 3 Content of fatty acids (mg fatty acids per $\mathrm{g}$ milk) in sow milk at day 4, 18 and 25 of lactation

\begin{tabular}{|c|c|c|c|c|c|c|c|c|c|c|c|c|c|c|c|c|c|c|}
\hline \multirow[b]{2}{*}{ Day } & \multicolumn{3}{|c|}{ Control } & \multicolumn{3}{|c|}{ Coconut oil } & \multicolumn{3}{|c|}{ Rapeseed oil } & \multicolumn{3}{|c|}{ Fish oil } & \multicolumn{3}{|c|}{ Sunflower oil } & \multirow[b]{2}{*}{ s.e. } & \multicolumn{2}{|c|}{ Significance } \\
\hline & 4 & 18 & 25 & 4 & 18 & 25 & 4 & 18 & 25 & 4 & 18 & 25 & 4 & 18 & 25 & & Diet & Sample \\
\hline 0:0 & 0.14 & 0.11 & 0.15 & 0.10 & 0.14 & 0.15 & 0.11 & 0.14 & 0.13 & 0.10 & 0.12 & 0.15 & 0.08 & 0.08 & 0.11 & 0.03 & ns & * \\
\hline $\mathrm{C} 12: 0$ & 1.43 & 0.76 & 0.23 & 0.69 & 2.20 & 3.04 & 0.89 & 0.88 & 0.21 & 0.17 & 0.18 & 0.25 & 0.19 & 0.12 & 0.18 & 0.80 & & ns \\
\hline C14:0 & 4.35 & 3.00 & 2.80 & 3.61 & 4.76 & 5.28 & 3.13 & 3.57 & 2.94 & 3.19 & 3.18 & 4.20 & 1.89 & 1.70 & 2.42 & 1.02 & * & ns \\
\hline C16:0 & 16.7 & 13.4 & 16.3 & 17.3 & 14.3 & 14.7 & 12.7 & 15.2 & 15.2 & 14.6 & 14.3 & 16.5 & 13.6 & 13.0 & 15.1 & 1.74 & ns & ns \\
\hline C16:1 & 7.43 & 5.85 & 7.13 & 6.28 & 7.07 & 6.97 & 5.37 & 5.67 & 5.52 & 6.45 & 6.59 & 7.40 & 4.26 & 4.70 & 4.02 & 0.89 & $* * *$ & ns \\
\hline C18:0 & 5.03 & 2.26 & 2.53 & 3.95 & 2.32 & 2.45 & 2.91 & 2.83 & 3.12 & 3.88 & 2.20 & 3.18 & 3.93 & 2.61 & 3.40 & 1.18 & ns & \\
\hline C18:1 & 17.8 & 12.4 & 12.1 & 22.7 & 12.6 & 14.2 & 17.1 & 19.7 & 19.7 & 17.4 & 11.8 & 13.9 & 16.8 & 11.2 & 13.0 & 2.56 & * & ** \\
\hline C18:2n-6 & 7.36 & 5.47 & 8.02 & 9.16 & 5.29 & 6.03 & 6.63 & 8.46 & 8.51 & 6.62 & 5.17 & 7.14 & 12.0 & 7.69 & 13.2 & 1.69 & $* *$ & * \\
\hline C18:3n-3 & 0.87 & 0.59 & 0.62 & 0.94 & 0.54 & 1.13 & 2.07 & 3.45 & 3.44 & 1.18 & 1.03 & 1.19 & 0.84 & 0.52 & 0.77 & 0.71 & $* * *$ & ns \\
\hline C20:1 & 0.25 & 0.04 & 0.01 & 0.34 & 0 & 0.15 & 0.19 & 0.25 & 0.34 & 0.79 & 0.63 & 0.96 & 0.20 & 0 & 0.06 & 0.18 & $* * *$ & ns \\
\hline C20:2 & 0.17 & 0.10 & 0.10 & 0.22 & 0.07 & 0.09 & 0.13 & 0.11 & 0.15 & 0.19 & 0.12 & 0.15 & 0.21 & 0.08 & 0.16 & 0.03 & ns & $* * *$ \\
\hline$C 20: 3 n-6$ & 0.43 & 0.23 & 0.27 & 0.56 & 0.26 & 0.22 & 0.29 & 0.1 & 0.24 & 0.35 & 0.20 & 0.27 & 0.56 & 0.20 & 0.36 & 0.08 & 115 & $* * *$ \\
\hline$C 20: 4 n-6$ & 0.06 & 0.03 & 0.02 & 0.08 & 0.02 & 0.04 & 0.06 & 0.06 & 0.09 & 0.10 & 0.07 & 0.07 & 0.05 & 0.02 & 0.02 & 0.01 & $* * *$ & $* *$ \\
\hline$C 20: 5 n-3$ & 0.11 & 0.05 & 0.03 & 0.12 & 0.07 & 0.08 & 0.10 & 0.10 & 0.14 & 1.83 & 2.00 & 2.14 & 0.05 & 0.08 & 0.02 & 0.21 & $* * *$ & ns \\
\hline$C 22: 5 n-6$ & 0.24 & 0.03 & 0.03 & 0.06 & 0.02 & 0.03 & 0.03 & 0.02 & 0.03 & 0.03 & 0.02 & 0.03 & 0.07 & 0.02 & 0.05 & 0.06 & ns & ns \\
\hline$C 22: 5 n-3$ & 0.18 & 0.09 & 0.07 & 0.24 & 0.10 & 0.10 & 0.14 & 0.09 & 0.24 & 0.47 & 0.44 & 0.46 & 0.16 & 0.07 & 0.07 & 0.06 & $* * *$ & * \\
\hline$C 22: 6 n-3$ & 0.20 & 0.06 & 0.04 & 0.29 & 0.12 & 0.09 & 0.14 & 0.08 & 0.66 & 2.46 & 2.65 & 2.60 & 0.11 & 0.09 & 0.03 & 0.35 & $* * *$ & ns \\
\hline SAFA & 27.8 & 19.5 & 22.1 & 25.7 & 23.8 & 25.6 & 19.8 & 22.6 & 21.7 & 22.0 & 20.1 & 24.4 & 19.7 & 17.6 & 21.3 & 3.35 & ns & ns \\
\hline MUFA & 25.5 & 18.3 & 19.3 & 29.4 & 19.7 & 21.3 & 22.6 & 25.6 & 25.6 & 24.7 & 19.0 & 22.2 & 21.3 & 15.9 & 17.1 & 2.81 & * & ** \\
\hline PUFA & 9.62 & 6.65 & 9.18 & 11.7 & 6.50 & 7.81 & 9.58 & 12.5 & 13.5 & 13.2 & 11.7 & 14.0 & 14.1 & 8.77 & 14.7 & 2.16 & ** & ns \\
\hline Total & 62.9 & 44.5 & 50.5 & 66.8 & 50.0 & 54.8 & 52.0 & 60.8 & 60.8 & 59.9 & 50.8 & 60.7 & 55.1 & 42.3 & 53.1 & 6.50 & ns & * \\
\hline$n-6$ & 8.08 & 5.76 & 8.33 & 9.85 & 5.59 & 6.32 & 7.00 & 8.73 & 8.85 & 7.10 & 5.46 & 7.50 & 12.7 & 7.93 & 13.7 & 1.74 & $* *$ & * \\
\hline$n-3$ & 1.34 & 0.78 & 0.74 & 1.59 & 0.83 & 1.40 & 2.45 & 3.71 & 4.41 & 5.93 & 6.12 & 6.39 & 1.16 & 0.76 & 0.88 & 0.833 & $* * *$ & ns \\
\hline$n-6: n-3$ & 6.23 & 7.39 & 10.5 & 6.94 & 6.79 & 6.11 & 3.55 & 3.41 & 1.94 & 1.24 & 0.91 & 1.36 & 11.0 & 11.8 & 15.5 & 1.70 & $* * *$ & Ns \\
\hline
\end{tabular}

Table 4 Effect of dietary treatment of sows on the concentration of selected fatty acids in plasma $(\mathrm{mg} / \mathrm{g})$ during suckling (pooled between 4,18 and 25 days of age)

\begin{tabular}{|c|c|c|c|c|c|c|c|}
\hline & Control & Coconut oil & Rapeseed oil & Fish oil & Sunflower oil & s.e. & Significance (diet) \\
\hline C12:0 & & & & $-^{+}$ & & & *** \\
\hline C14:0 & $0.07^{a}$ & $0.16^{\mathrm{b}}$ & $0.04^{\mathrm{a}}$ & $0.05^{\mathrm{a}}$ & $0.05^{\mathrm{a}}$ & 0.02 & $* * *$ \\
\hline C16:0 & 1.6 & 1.7 & 1.1 & 1.2 & 1.3 & 0.17 & ns \\
\hline C16:1 & $0.43^{b}$ & $0.36^{b}$ & $0.14^{\mathrm{a}}$ & $0.20^{\mathrm{ab}}$ & $0.17^{\mathrm{a}}$ & 0.05 & $* * *$ \\
\hline C18:0 & 0.59 & 0.70 & 0.51 & 0.52 & 0.52 & 0.07 & ns \\
\hline $\mathrm{C} 18: 1^{\neq}$ & $1.4^{b}$ & $1.5^{b}$ & $1.5^{b}$ & $0.98^{a}$ & $1.1^{\mathrm{a}}$ & 0.19 & ns \\
\hline C18:2n-6 & 1.3 & 1.7 & 1.3 & 0.87 & 1.7 & 0.17 & ** \\
\hline C18:3n-3 & $0.04^{a}$ & $0.04^{\mathrm{a}}$ & $0.13^{b}$ & $0.05^{\mathrm{a}}$ & $0.03^{\mathrm{a}}$ & $<0.01$ & $* * * *$ \\
\hline C20:2 & 0.01 & 0.01 & $<0.01$ & $<0.01$ & $<0.01$ & $<0.01$ & ns \\
\hline$C 20: 3 n-6$ & $0.37^{b}$ & $0.37^{b}$ & $0.21^{a}$ & $0.18^{\mathrm{a}}$ & $0.34^{b}$ & 0.05 & $* * *$ \\
\hline$C 20: 4 n-6^{\S}$ & - & - & - & -\$ & - & - & - \\
\hline$C 20: 5 n-3$ & $0.01^{\mathrm{a}}$ & $0.04^{\mathrm{a}}$ & $0.05^{\mathrm{a}}$ & $0.48^{\mathrm{b}}$ & $0.03^{\mathrm{a}}$ & 0.04 & $* * *$ \\
\hline$C 22: 5 n-6$ & 0.01 & $<0.01$ & 0.01 & $<0.01$ & 0.01 & $<0.01$ & * \\
\hline$C 22: 5 n-3$ & $0.04^{\mathrm{a}}$ & $0.04^{a}$ & $0.04^{\mathrm{a}}$ & $0.05^{b}$ & $0.01^{\mathrm{a}}$ & 0.01 & * \\
\hline$C 22: 6 n-3$ & $0.07^{\mathrm{a}}$ & $0.13^{b}$ & $0.07^{a}$ & $0.28^{\mathrm{C}}$ & $0.06^{\mathrm{a}}$ & 0.02 & $* * *$ \\
\hline SAFA & 2.2 & 2.6 & 1.6 & 1.8 & 1.9 & 0.25 & ns \\
\hline MUFA & $1.8^{\mathrm{b}}$ & $1.8^{\mathrm{b}}$ & $1.6^{\mathrm{ab}}$ & $1.2^{\mathrm{a}}$ & $1.3^{\mathrm{a}}$ & 0.20 & * \\
\hline PUFA & 1.9 & 2.3 & 1.8 & 1.9 & 2.0 & 0.24 & ns \\
\hline Total & 5.9 & 6.7 & 5.0 & 5.0 & 4.7 & 0.65 & ns \\
\hline$n-6$ & $1.3^{\mathrm{ab}}$ & $1.7^{\mathrm{b}}$ & $1.3^{b}$ & $0.89^{a}$ & $1.5^{b}$ & 0.18 & ** \\
\hline$n-3$ & $0.16^{\mathrm{a}}$ & $0.25^{\mathrm{a}}$ & $0.28^{\mathrm{a}}$ & $0.87^{b}$ & $0.15^{\mathrm{a}}$ & 0.06 & $* * *$ \\
\hline$n-6: n-3$ & $8.3^{b}$ & $6.9^{b}$ & $4.5^{\mathrm{ab}}$ & $1.3^{\mathrm{a}}$ & $13.0^{c}$ & 1.4 & $* * *$ \\
\hline
\end{tabular}

\footnotetext{
a,b,c Means within a row with different superscripts are significantly different $(P \leqslant 0.05)$.

${ }^{\dagger}$ Piglets of coconut oil treatment, $0.028(0.005) \mathrm{mg} / \mathrm{g}$, other groups below $0.001 \mathrm{mg} / \mathrm{g}$.

${ }^{\ddagger}$ Effect of age: $P=0.019$.

${ }^{\S} \mathrm{C} 20: 4 \mathrm{n}-6$ was not detectable in the plasma.
} 
Significant interactions between dietary treatments and age of piglets were obtained on C16:1 $(P=0.016), C 18: 2$ $(P=0.013), C 18: 3 \quad(P=0.045), C 20: 3 \quad(P=0.004)$ and C20:4 $(P=0.037)$ in adipose tissue (Table 5), i.e. the proportion of $C 18: 2$ and $C 18: 3$ decreased from day 4 to day 18 of age when piglets sucked sows fed control, animal fat, rapeseed oil (not C18:3) and fish oil, whereas the proportion of the fatty acids increased in the same age period when sunflower oil was given to the sows. With regard to the proportion of $\mathrm{C} 16: 1$ in adipose tissue, the opposite trend was observed, i.e. decrease with age when piglets were sucking sows fed sunflower oil. Likewise, significant interactions between dietary treatments and age of piglets were observed on the proportion of SAFA, PUFA and $n-6$ fatty acids, as for example a decrease in PUFA and $n-6$ with progressing age was observed when piglets sucking sows fed coconut oil, whereas an increase was observed on these responses with the sunflower oil. When considering the ages of 18 and 25 days, the content of PUFA and the ratio of $n-6$ and $n-3$ was influenced by the dietary treatments as sunflower oil contributed with the highest proportion of PUFA and $n-6: n-3$ fatty acid ratio.

Dietary treatment of sows influenced the fatty acid composition of the liver during the suckling period (Table 6), and overall the $n-6: n-3$ ratio was the highest in the liver of piglets of the sows on sunflower oil and lowest when fish oil was the supplement, whereas the proportion of SAFA, MUFA and PUFA was less affected. The concentration of C14:0 $(P=0.005), C 16: 0(P=0.018), C 18: 1 \quad(P=0.002)$, MUFA $(P<0.001)$ and total fatty acids $(P=0.02)$ was higher in the liver obtained from piglets at day 4 of age compared with later on during the suckling period. Only the concentration of $\mathrm{C} 20: 4$ was influenced by an interaction between dietary treatment and age of piglets $(P=0.05)$, as this fatty acid decreased with age when piglets sucked sows fed fish oil, but increased when sunflower oil was provided to the sows.

\section{Piglet responses during the period after weaning}

The performance of the piglets during the post-weaning period was not influenced by the dietary treatment of the sows, and the weight gain from weaning to day 49 of age varied from $1.81 \mathrm{~kg}$ (rapeseed oil) to $3.30 \mathrm{~kg}$ (coconut oil), s.e. $=0.84 \mathrm{~kg}$, and the feed intake ranged from $4.87 \mathrm{~kg}$ (coconut oil) to $7.66 \mathrm{~kg}$ (sunflower oil), s.e. $=0.65 \mathrm{~kg}$.

In general, weaning (change from days 25 to 35 ) decreased the concentration of the lipid-soluble extracts in the plasma, e.g. the total content of fatty acids decreased from a concentration of total fatty acids in plasma (Table 7) at day $25 ; 5.32 \mathrm{mg} / \mathrm{l}$ v. 3.32 (day 35 of age). Of the shown responses (glycerol, FFA, glucose, cholesterol, triglycerides, total fatty acids and vitamin E) in Table 7, only vitamin E concentration was influenced by the dietary treatment of sows as the concentration of vitamin $E$ in plasma was highest $(2.86 \mathrm{mg} / \mathrm{l}$ plasma $)$ in piglets sucking sows fed coconut oil, and lowest $(1.52 \mathrm{mg} / \mathrm{l})$ in plasma of piglets of the sows on sunflower oil.

When the fatty acid composition of plasma was analysed during the period after weaning, dietary treatments of sows showed a significant influence on the concentration of SAFA $(P=0.043)$, PUFA $(P=0.027), \mathrm{n}-6$ fatty acids $(P=0.004)$

Table 5 Effect of dietary treatment of sows on the relative distribution of selected fatty acids in adipose tissue (\%) during suckling

\begin{tabular}{|c|c|c|c|c|c|c|c|c|c|c|c|c|c|c|c|c|c|c|c|}
\hline \multirow{2}{*}{$\begin{array}{l}\text { Age } \\
\text { (days) }\end{array}$} & \multicolumn{3}{|c|}{ Control } & \multicolumn{3}{|c|}{ Coconut oil } & \multicolumn{3}{|c|}{ Rapeseed oil } & \multicolumn{3}{|c|}{ Fish oil } & \multicolumn{3}{|c|}{ Sunflower oil } & \multicolumn{4}{|c|}{ Significance } \\
\hline & 4 & 18 & 25 & 4 & 18 & 25 & 4 & 18 & 25 & 4 & 18 & 25 & 4 & 18 & 25 & s.e. & Diet & Age & Diet $\times$ age \\
\hline $\mathrm{C} 12: 0$ & $<0.0$ & 0.03 & 0.05 & 0.03 & 0.73 & 1.34 & 0.06 & 0.11 & 0.10 & 0.05 & 0.11 & 0.10 & 0.45 & 0.09 & 0.08 & 0.24 & $* * *$ & ns & ** \\
\hline C14:0 & 2.63 & 2.79 & 2.41 & 2.43 & 4.63 & 7.23 & 2.07 & 2.29 & 2.55 & 2.79 & 2.49 & 2.82 & 3.69 & 2.24 & 2.06 & 0.69 & ** & ns & * \\
\hline C16:0 & 27.4 & 31.1 & 26.8 & 25.2 & 28.2 & 29.4 & 22.5 & 22.7 & 23.2 & 25.5 & 25.0 & 24.5 & 25.6 & 24.7 & 24.2 & 1.37 & $* * *$ & ns & ns \\
\hline C16:1 & 8.68 & 14.1 & 11.5 & 7.58 & 10.4 & 13.0 & 5.74 & 6.90 & 8.02 & 8.77 & 9.32 & 10.5 & 8.44 & 7.93 & 6.68 & 31.07 & $* * *$ & $\star *$ & * \\
\hline C18:0 & 5.48 & 5.87 & 9.27 & 6.82 & 7.02 & 7.00 & 5.69 & 8.00 & 8.65 & 5.82 & 7.97 & 9.41 & 6.62 & 6.14 & 7.39 & 1.23 & ns & * & ns \\
\hline C18:1 & 38.8 & 35.2 & 35.7 & 39.8 & 39.4 & 32.8 & 44.9 & 42.6 & 36.8 & 38.9 & 38.1 & 34.4 & 39.6 & 35.4 & 35.8 & 2.69 & ns & $\star *$ & ns \\
\hline C18:2n-6 & 14.5 & 9.33 & 9.08 & 13.4 & 7.84 & 7.61 & 14.8 & 11.5 & 13.1 & 10.6 & 8.38 & 8.39 & 13.0 & 21.0 & 21.4 & 2.21 & $* * *$ & ns & * \\
\hline C18:3n-3 & 1.32 & 0.84 & 1.00 & 1.02 & 0.68 & 0.63 & 2.74 & 3.85 & 4.84 & 1.49 & 1.32 & 1.44 & 0.81 & 0.92 & 0.83 & 0.38 & $* * *$ & ns & * \\
\hline$C 20: 3 n-6$ & 0.84 & 0.02 & 0.11 & 0.13 & 0.18 & 0.26 & 0.40 & 0.11 & 0.13 & 0.52 & 0.29 & 0.30 & 0.32 & 0.09 & 0.43 & 0.07 & $* * *$ & * & $* *$ \\
\hline$C 20: 4 n-6$ & $<0.0$ & 0.02 & 0.09 & 0.06 & 0.02 & 0.04 & 0.05 & 0.26 & 0.34 & 0.07 & 0.15 & 0.16 & 0.03 & 0.08 & 0.08 & 30.04 & $* * *$ & $\star *$ & * \\
\hline$C 20: 5 n-3$ & $<0.0$ & $<0.0$ & 0.52 & 0.61 & 0.05 & 0.03 & 0.04 & 0.04 & 0.11 & 1.34 & 1.52 & 1.82 & 0.07 & 0.02 & $<0.0$ & 0.23 & $* * *$ & ns & ns \\
\hline$C 22: 5 n-3$ & $<0.0$ & 0.03 & 0.56 & 0.45 & 0.11 & 0.12 & 0.12 & 0.17 & 0.26 & 0.81 & 1.09 & 1.17 & 0.16 & 0.13 & 0.11 & 0.20 & $* * *$ & ns & ns \\
\hline$C 22: 6 n-3$ & $<0.0$ & 0.03 & 1.73 & 1.48 & 0.24 & 0.19 & 0.10 & 0.16 & 0.17 & 2.74 & 3.66 & 3.77 & 0.29 & 0.11 & 0.09 & 0.67 & $* * *$ & $* *$ & ns \\
\hline SAFA & 35.5 & 39.8 & 38.7 & 34.5 & 40.6 & 45.1 & 30.4 & 33.2 & 34.6 & 34.3 & 35.8 & 37.1 & 36.4 & 33.3 & 33.8 & 1.70 & $* * *$ & * & * \\
\hline MUFA & 47.8 & 49.4 & 47.8 & 48.1 & 50.1 & 45.9 & 51.1 & 50.2 & 45.7 & 48.0 & 47.5 & 45.5 & 48.6 & 43.3 & 42.6 & 2.31 & ns & * & ns \\
\hline PUFA & 16.7 & 10.8 & 13.6 & 17.3 & 9.24 & 9.07 & 18.5 & 16.6 & 19.7 & 17.8 & 16.8 & 17.4 & 15.0 & 23.4 & 23.6 & 2.36 & ns & ns & * \\
\hline Total & 100 & 100 & 100 & 100 & 100 & 100 & 100 & 100 & 100 & 100 & 100 & 100 & 100 & 100 & 100 & & & & \\
\hline$n-6$ & 14.5 & 9.37 & 9.22 & 13.5 & 7.87 & 7.68 & 14.8 & 11.8 & 13.5 & 10.7 & 8.58 & 8.59 & 13.1 & 21.2 & 21.5 & 2.22 & $* * *$ & ns & * \\
\hline$n-3$ & 1.32 & 0.91 & 3.80 & 3.55 & 1.08 & 0.98 & 3.00 & 4.22 & 5.38 & 6.39 & 7.59 & 8.19 & 1.33 & 1.17 & 1.04 & 1.26 & $* * *$ & ns & ns \\
\hline$n-6: n-3$ & 11.0 & 10.4 & 7.46 & 12.2 & 7.87 & 7.91 & 6.11 & 2.95 & 2.52 & 1.73 & 1.14 & 1.05 & 10.3 & 18.4 & 20.7 & 3.06 & $* * *$ & ns & ns \\
\hline
\end{tabular}


Lauridsen and Jensen

Table 6 Effect of dietary treatment of sows and age of piglets on the concentration of selected fatty acids in liver (mg/100 g) during suckling

\begin{tabular}{|c|c|c|c|c|c|c|c|c|c|c|c|c|c|c|c|c|c|c|}
\hline \multirow[b]{2}{*}{ Age (days) } & \multicolumn{3}{|c|}{ Control } & \multicolumn{3}{|c|}{ Coconut oil } & \multicolumn{3}{|c|}{ Rapeseed oil } & \multicolumn{3}{|c|}{ Fish oil } & \multicolumn{3}{|c|}{ Sunflower oil } & \multirow[b]{2}{*}{ s.e. } & \multicolumn{2}{|c|}{ Significance } \\
\hline & 4 & 18 & 25 & 4 & 18 & 25 & 4 & 18 & 25 & 4 & 18 & 25 & 4 & 18 & 25 & & Diet & Age \\
\hline 14:0 & 0.69 & 0.41 & 0.38 & 2.26 & 0.90 & 0.95 & 0.63 & 0.35 & 0.23 & 1.20 & 0.36 & 0.59 & 0.90 & 0.38 & 0.31 & 0.18 & . & ** \\
\hline C16:0 & 17.7 & 13.6 & 14.2 & 23.7 & 13.0 & 12.9 & 16.3 & 12.4 & 11.4 & 21.9 & 12.3 & 15.0 & 18.1 & 13.5 & 13.7 & 1.77 & ns & * \\
\hline C16:1 & 0.41 & 0.41 & 0.48 & 0.41 & 0.36 & 0.43 & 0.24 & 0.19 & 0.14 & 0.25 & 0.23 & 0.30 & 0.30 & 0.22 & 0.15 & 0.03 & $* * *$ & ns \\
\hline C18:0 & 12.0 & 13.3 & 14.6 & 14.0 & 12.2 & 13.8 & 13.4 & 14.3 & 15.5 & 15.1 & 16.1 & 15.7 & 13.6 & 14.7 & 15.5 & 0.88 & ns & ns \\
\hline C18:1 & 17.3 & 8.51 & 9.25 & 24.5 & 7.83 & 7.18 & 22.5 & 10.7 & 9.34 & 17.8 & 7.42 & 7.08 & 19.8 & 7.00 & 6.39 & 2.60 & ns & $* *$ \\
\hline C18:2n-6 & 10.4 & 7.95 & 8.58 & 12.9 & 8.23 & 8.13 & 11.4 & 11.3 & 11.8 & 10.4 & 5.72 & 6.06 & 16.0 & 13.0 & 15.6 & 1.14 & $* * *$ & ns \\
\hline C18:3n-3 & 0.33 & 0.56 & 0.31 & 0.46 & 0.23 & 0.45 & 1.26 & 1.18 & 1.22 & 0.98 & 0.42 & 0.59 & 0.53 & 0.36 & 0.15 & 0.13 & $* * *$ & ns \\
\hline$C 20: 3 n-6$ & 0.43 & 0.63 & 0.52 & 0.83 & 0.63 & 0.51 & 0.56 & 0.56 & 0.65 & 0.28 & 0.22 & 0.23 & 0.47 & 0.37 & 0.36 & 0.07 & $* *$ & ns \\
\hline$C 20: 4 n-6^{+}$ & 9.19 & 8.89 & 9.87 & 9.49 & 6.81 & 6.98 & 8.23 & 7.08 & 7.44 & 6.19 & 4.11 & 3.70 & 9.08 & 10.9 & 10.5 & 0.48 & $* * *$ & ns \\
\hline$C 20: 5 n-3$ & 0.12 & 0.22 & 0.26 & 0.43 & 0.43 & 0.33 & 0.64 & 0.65 & 1.04 & 5.88 & 6.52 & 7.30 & 0.13 & 0.08 & 0.12 & 0.32 & $* * *$ & ns \\
\hline$C 22: 5 n-3$ & 0.83 & 1.07 & 1.23 & 1.10 & 0.86 & 0.90 & 0.97 & 1.14 & 2.04 & 2.36 & 1.61 & 1.92 & 0.62 & 0.83 & 1.18 & 0.16 & $* * *$ & * \\
\hline C22:6n-3 & 2.67 & 2.81 & 3.84 & 5.37 & 4.01 & 4.30 & 3.42 & 3.70 & 3.53 & 10.1 & 10.3 & 11.9 & 2.94 & 2.68 & 3.15 & 0.67 & $* * *$ & ns \\
\hline SAFA & 30.4 & 27.3 & 29.1 & 39.9 & 26.1 & 27.6 & & 27.0 & 13.5 & 38.1 & 28.7 & 30.8 & 32.6 & 28.6 & 29.5 & 2.43 & ns & ns \\
\hline MUFA & 17.9 & 8.97 & 9.79 & 25.1 & 8.27 & 7.66 & 22.9 & 11.0 & 4.77 & 18.4 & 7.80 & 7.58 & 20.3 & 7.28 & 6.62 & 0.63 & ns & $* * *$ \\
\hline PUFA & 24.2 & 22.4 & 24.8 & 30.9 & 21.4 & 21.8 & 26.9 & 25.8 & 14.0 & 36.4 & 29.1 & 31.9 & 30.1 & 28.6 & 31.4 & 2.11 & * & ns \\
\hline Total & 72.5 & 58.7 & 63.6 & 96.0 & 55.8 & 57.1 & 80.1 & 63.8 & 32.3 & 92.9 & 65.6 & 70.3 & 83.1 & 64.5 & 67.5 & 6.67 & ns & * \\
\hline$n-6$ & 20.1 & 17.5 & 19.0 & 23.3 & 15.7 & 15.7 & 20.4 & 19.0 & 9.96 & 16.9 & 10.1 & 10.0 & 25.6 & 24.4 & 26.4 & 1.47 & $* * *$ & ns \\
\hline$n-3$ & 3.96 & 4.65 & 5.65 & 7.36 & 5.53 & 6.00 & 6.29 & 6.66 & 3.92 & 19.3 & 18.9 & 22.7 & 4.22 & 3.95 & 4.61 & 1.01 & $* * *$ & ns \\
\hline$n-6: n-3$ & 5.09 & 3.77 & 3.36 & 3.20 & 2.90 & 2.65 & 3.26 & 2.86 & 2.41 & 0.80 & 0.54 & 0.48 & 5.93 & 6.43 & 5.94 & 0.28 & $* * *$ & ns \\
\hline
\end{tabular}

${ }^{+}$Interaction between diet and age, $P=0.05$.

Table 7 Effect of age of piglets on nutritional status measured in plasma of piglets pre- and post weaning ${ }^{\dagger}$

\begin{tabular}{|c|c|c|c|c|c|c|c|c|}
\hline & \multicolumn{6}{|c|}{ Age of piglets (days) } & \multirow[b]{2}{*}{ s.e. } & \multirow[b]{2}{*}{ Significance (age) } \\
\hline & 4 & 18 & 25 & 35 & 42 & 49 & & \\
\hline Glycerol & 102 & 130 & 100 & 94.5 & 115 & 65.2 & 23.9 & ns \\
\hline FFA & $0.33^{c}$ & $0.314^{c}$ & $0.356^{c}$ & $0.275^{b}$ & $0.153^{a}$ & $0.15^{\mathrm{a}}$ & 0.027 & $* * *$ \\
\hline Glucose & $7.35^{\mathrm{a}}$ & $10.1^{\mathrm{b}}$ & $8.20^{\mathrm{a}}$ & $7.37^{\mathrm{a}}$ & $8.24^{\mathrm{a}}$ & $7.82^{\mathrm{a}}$ & 0.706 & * \\
\hline Cholesterol & $3.28^{\mathrm{b}}$ & $4.13^{c}$ & $3.82^{c}$ & $1.98^{\mathrm{a}}$ & $1.80^{\mathrm{a}}$ & $1.81^{a}$ & 0.290 & $* * *$ \\
\hline Triglyceride & $0.47^{b}$ & $0.51^{\mathrm{b}}$ & $0.512^{b}$ & $0.467^{b}$ & $0.388^{\mathrm{ab}}$ & $0.282^{\mathrm{a}}$ & 0.066 & * \\
\hline Total fatty acids & 5.91 & $5.58^{\mathrm{b}}$ & $5.32^{\mathrm{b}}$ & $3.32^{\mathrm{a}}$ & $3.18^{\mathrm{a}}$ & $2.95^{\mathrm{a}}$ & 0.38 & $* * *$ \\
\hline Vitamin $\mathrm{E}^{\ddagger}$ & $4.74^{c}$ & $3.03^{b}$ & $2.57^{\mathrm{b}}$ & $1.09^{\mathrm{a}}$ & $0.889^{\mathrm{a}}$ & $0.87^{\mathrm{a}}$ & 0.77 & * \\
\hline
\end{tabular}

a,b,c Means within a row with different superscripts are significantly different $(P \leqslant 0.05)$.

${ }^{\dagger}$ No effect of diets (except vitamin E) was obtained, and results are therefore pooled between dietary treatments.

${ }^{\ddagger}$ Effect of diet: $P=0.027$.

and the $\mathrm{n}-6: \mathrm{n}-3$ ratio $(P=0.051)$ as shown in Table 8 . Age of piglets influenced the concentration of $\mathrm{C} 16: 1$ $(P=0.002)$, as a decrease in the concentration was obtained with progressing age. In addition, age influenced the plasma concentration of $\mathrm{C} 20: 5(P=0.014)$ and $\mathrm{C} 22: 5$ $(P=0.011)$.

The fatty acid composition of the adipose tissue of piglets post weaning was largely influenced by the dietary treatments of the sows, whereas age of the piglets had minor effect on the adipose tissue (Table 9). The n-6:n-3 fatty acid ratio observed in the adipose tissue post weaning followed the same pattern with regard to the dietary treatment of sows as observed for the samples obtained during the suckling period, i.e. piglets of the sows on sunflower oil had the highest ratio and piglets of the sows on fish oil had the lowest ratio. Likewise, piglets of the sows on sunflower oil showed the highest proportion of PUFA in the adipose tissue post weaning.

Age, rather than dietary treatments of sows, influenced the liver fatty acid composition of the piglets post weaning (Table 10). Overall, the concentration of fatty acids in liver was lower post- than pre weaning but no general trend regarding the changes in the fatty acid composition with progressing age could be given. Dietary treatments of sows affected the total concentration of fatty acids in the liver of pigs, i.e. piglets of sows fed sunflower oil had a higher concentration of the $n-6$ fatty acids (C18:2 and C20:4) as well as total fatty acids post weaning. Although the $n-6: n-3$ ratio was affected by the dietary treatments, the relative differences were much less pronounced than obtained for the adipose tissue postweaning. 
Maternal dietary lipids and effects on progeny

Table 8 Effect of dietary treatment of sows on the concentration of selected fatty acids in plasma (mg/100 g) post weaning (pooled between 35, 42 and 49 days of age)

\begin{tabular}{|c|c|c|c|c|c|c|c|}
\hline & Control & Coconut oil & Rapeseed oil & Fish oil & Sunflower oil & s.e. & Significance (diets) \\
\hline $\mathrm{C} 14: 0$ & 2.44 & 3.34 & 2.23 & 2.48 & 3.30 & 0.51 & ns \\
\hline $\mathrm{C} 16: 0$ & 62.4 & 76.4 & 66.3 & 51.1 & 88.1 & 9.11 & ns \\
\hline $\mathrm{C} 16: 1^{\dagger}$ & 8.84 & 11.6 & 6.65 & 7.30 & 11.3 & 2.27 & ns \\
\hline C18:0 & 32.3 & 36.4 & 33.7 & 27.3 & 40.0 & 3.59 & ns \\
\hline C18:1 & 82.4 & 80.8 & 87.0 & 67.4 & 89.4 & 7.42 & ns \\
\hline C18:2n-6 & $64.4^{\mathrm{ab}}$ & $71.6^{\mathrm{bc}}$ & $74.7^{\mathrm{bc}}$ & $55.3^{\mathrm{a}}$ & $93.8^{b c}$ & 7.91 & ** \\
\hline C18:3n-3 & 2.77 & 3.23 & 3.86 & 2.48 & 3.50 & 0.48 & ns \\
\hline$C 20: 3 n-6$ & $17.1^{\mathrm{b}}$ & $16.2^{b}$ & $14.9^{b}$ & $7.30^{\mathrm{a}}$ & $21.1^{\mathrm{b}}$ & 2.71 & $* * *$ \\
\hline$C 20: 4 n-6^{\ddagger}$ & - & - & - & $-^{\ddagger}$ & - & - & - \\
\hline$C 20: 5 n-3^{\S}$ & 8.54 & 19.3 & 3 & 15.6 & 17.2 & 4.94 & ns \\
\hline$C 22: 5 n-3$ & 2.37 & 2.83 & 3.00 & 2.81 & 5.86 & 0.43 & ns \\
\hline$C 22: 6 n-3$ & 9.12 & 12.2 & 9.64 & 11.0 & 13.0 & 2.13 & ns \\
\hline SAFA & $97.2^{\mathrm{ab}}$ & $116^{b}$ & $102^{a b}$ & $80.3^{a}$ & $131^{b}$ & 12.8 & * \\
\hline MUFA & 91.7 & 92.8 & 94.3 & 75.1 & 101 & 9.00 & ns \\
\hline PUFA & $105^{\mathrm{a}}$ & $126^{\mathrm{ab}}$ & $116^{\mathrm{ab}}$ & $92.5 \mathrm{a}$ & $153^{b}$ & 13.7 & * \\
\hline Total & 293 & 335 & 313 & 27.9 & 385 & 34.1 & ns \\
\hline$n-6$ & $64.6^{\mathrm{ab}}$ & $71.6^{\mathrm{ab}}$ & $74.6^{b}$ & $53.3^{a}$ & $94.3^{b}$ & 34.1 & ** \\
\hline$n-3$ & 22.8 & 38.1 & 26.8 & 31.9 & 36.8 & 8.30 & ns \\
\hline$n-6: n-3$ & 2.89 & 2.39 & 2.81 & 1.88 & 3.42 & 0.35 & * \\
\hline
\end{tabular}

a,b,c Means within a row with different superscripts are significantly different $(P \leqslant 0.05)$.

${ }^{\dagger}$ Effect of age, $P=0.002$.

${ }^{\ddagger} \mathrm{C} 20: 4 \mathrm{n}-6$ was not detectable in the plasma.

EEffect of age, $P=0.014$.

Effect of age, $P=0.011$.

Table 9 Effect of dietary treatment of sows and age of piglets on the fatty acid composition of adipose tissue (\%) post weaning

\begin{tabular}{|c|c|c|c|c|c|c|c|c|c|c|c|c|c|c|c|c|c|c|}
\hline \multirow{2}{*}{$\begin{array}{l}\text { Age } \\
\text { (days) }\end{array}$} & \multicolumn{3}{|c|}{ Control } & \multicolumn{3}{|c|}{ Coconut oil } & \multicolumn{3}{|c|}{ Rapeseed oil } & \multicolumn{3}{|c|}{ Fish oil } & \multicolumn{3}{|c|}{ Sunflower oil } & \multirow[b]{2}{*}{ s.e. } & \multicolumn{2}{|c|}{ Significance } \\
\hline & 35 & 42 & 49 & 35 & 42 & 49 & 35 & 42 & 49 & 35 & 42 & 49 & 35 & 42 & 49 & & Diet & Age \\
\hline 12:0 & 0.06 & 0.02 & 0.60 & 56 & 34 & 33 & 11 & 53 & 02 & 08 & 08 & 0.08 & 0.09 & 0.02 & .08 & 0.41 & * & ns \\
\hline 14:0 & 2.50 & 2.14 & 4.17 & 4.29 & 5.08 & 4.69 & 2.83 & 3.87 & 1.81 & 2.54 & 2.94 & 2.16 & 2.30 & 2.00 & 2.02 & 1.84 & * & ns \\
\hline C16:0 & 28.4 & 29.2 & 28.8 & 27.9 & 28.5 & 27.9 & 26.6 & 25.5 & 24.4 & 25.8 & 28.9 & 26.3 & 23.8 & 25.8 & 25.5 & 3.36 & ns & ns \\
\hline $16: 1$ & 13.0 & 10.3 & 9.87 & 9.34 & 9.79 & 8.74 & 8.13 & 8.52 & 4.62 & 10.2 & 10.7 & 7.19 & 7.13 & 6.51 & 5.93 & 2.67 & ** & * \\
\hline C18:0 & 8.33 & 8.44 & 8.25 & 8.04 & 6.40 & 7.00 & 6.33 & 7.45 & 8.23 & 7.35 & 8.56 & 9.48 & 9.25 & 5.82 & 8.23 & 1.40 & ns & ns \\
\hline C18:1 & 36.9 & 38.8 & 36.2 & 37.8 & 38.0 & 35.0 & 32.9 & 39.2 & 45.2 & 37.3 & 32.2 & 39.4 & 33.4 & 35.3 & 35.6 & 6.61 & ns & ns \\
\hline C18:2n-6 & 8.76 & 9.14 & 9.35 & 9.10 & 8.70 & 13.6 & 14.9 & 11.1 & 11.4 & 7.72 & 8.40 & 8.07 & 21.1 & 22.3 & 18.6 & 3.01 & $* * *$ & ns \\
\hline C18:3n-3 & 0.71 & 0.81 & 0.87 & 1.50 & 1.36 & 0.83 & 5.23 & 2.47 & 2.00 & 1.16 & 1.14 & 1.06 & 0.95 & 0.80 & 0.85 & 1.08 & $* * *$ & ns \\
\hline $20: 1$ & 0.27 & 0.54 & 0.50 & 0.20 & 0.46 & 0.46 & 1.0 & 0 & 0.80 & 0.49 & 0.08 & 1.07 & 0 & 0.2 & 0.30 & 0.33 & ns & ns \\
\hline$C 20: 2$ & 0.24 & 0.16 & 0.16 & 0.20 & 0.17 & 0.25 & 0.43 & 0.29 & 0.26 & 0.26 & 0.26 & 0.24 & 0.81 & 0.43 & .49 & 0.13 & $* * *$ & * \\
\hline$C 20: 3 n-6$ & 0.30 & 0.20 & 0.23 & 0.22 & 0.24 & 0.37 & 0.29 & 0.23 & 0.17 & 0.26 & 0.26 & 0.21 & 0.47 & 0.35 & 0.30 & 0.12 & ns & ns \\
\hline$C 20: 4 n-6$ & 0.03 & 0.03 & 0.03 & 0.10 & 0.06 & 0 & 0.41 & 0.24 & 0.05 & 0.12 & 0.16 & 0.03 & 0.10 & 0.03 & 0.08 & 0.11 & ns & ns \\
\hline $20: 5 n-3$ & 0.01 & & 0.19 & 0.06 & 0.03 & 0.90 & 0.07 & 0.05 & 0.08 & 1.32 & 0.50 & 0.03 & 0.02 & 0 & 0.14 & 0.17 & $* * *$ & * \\
\hline$C 22: 5 n-3$ & 0.14 & 0.06 & 0.19 & 0.19 & 0.10 & 0.12 & 0.26 & 0.20 & 0.29 & 1.18 & 1.28 & 0.85 & 0.14 & 0.04 & 0.22 & 0.12 & $* * *$ & ns \\
\hline$C 22: 6 n-3$ & 0.20 & 0.05 & 0.45 & 0.28 & 0.23 & 0.27 & 0.20 & 0.21 & 0.65 & 3.93 & 4.37 & 2.82 & 0.14 & 0.11 & 0.44 & 0.36 & *** & ** \\
\hline SAFA & 39.4 & 39.9 & 41.9 & 40.9 & 40.9 & 40.2 & 36.0 & 37.5 & 34.5 & 35.9 & 40.6 & 38.2 & 35.6 & 33.7 & 36.0 & 5.05 & * & ns \\
\hline MUFA & 50.2 & 49.6 & 46.6 & 47.4 & 48.2 & 44.3 & 42.1 & 47.7 & 50.6 & 48.1 & 43.0 & 47.7 & 40.5 & 42.2 & 42.8 & 4.81 & ns & ns \\
\hline PUFA & 10.5 & 10.5 & 11.6 & 11.7 & 10.9 & 15.5 & 21.9 & 11.3 & 14.9 & 16.0 & 16.4 & 14.2 & 23.9 & 24.1 & 21.2 & 4.08 & $* * *$ & ns \\
\hline Total & 100 & 100 & 100 & 100 & 100 & 100 & 100 & 100 & 100 & 100 & 100 & 100 & 100 & 100 & 100 & - & - & - \\
\hline$n-6$ & 8.85 & 9.21 & 9.43 & 9.25 & 8.80 & 13.6 & 15.4 & 11.3 & 11.5 & 7.89 & 8.57 & 8.10 & 21.3 & 22.4 & 18.8 & 3.08 & $* * *$ & ns \\
\hline$n-3$ & 1.07 & 0.91 & 1.71 & 2.03 & 1.72 & 1.31 & 5.76 & 2.94 & 3.01 & 7.58 & 7.29 & 5.61 & 1.25 & 0.95 & 1.65 & 1.28 & $\star \star * *$ & ns \\
\hline$n-6: n-3$ & 8.40 & 10.4 & 7.03 & 6.08 & 6.75 & 12.4 & 2.90 & 4.81 & 3.85 & 1.05 & 1.18 & 1.50 & 17.2 & 24.2 & 12.7 & 3.87 & *** & ns \\
\hline
\end{tabular}

${ }^{\dagger}$ Significant interactions between diet and age were not obtained. 
Lauridsen and Jensen

Table 10 Effect of dietary treatment of sows on the concentration of selected fatty acids in liver (mg/ $100 \mathrm{~g})$ post weaning

\begin{tabular}{|c|c|c|c|c|c|c|c|c|c|c|c|c|c|c|c|c|c|c|}
\hline \multirow[b]{2}{*}{ Age (days) } & \multicolumn{3}{|c|}{ Control } & \multicolumn{3}{|c|}{ Coconut oil } & \multicolumn{3}{|c|}{ Rapeseed oil } & \multicolumn{3}{|c|}{ Fish oil } & \multicolumn{3}{|c|}{ Sunflower oil } & \multirow[b]{2}{*}{ s.e. } & \multicolumn{2}{|c|}{ Significance } \\
\hline & 35 & 42 & 49 & 35 & 42 & 49 & 35 & 42 & 49 & 35 & 42 & 49 & 35 & 42 & 49 & & Diet & Age \\
\hline C14:0 & 0.24 & 0.28 & 0.28 & 0.54 & 0.31 & 0.25 & 0.34 & 0.21 & 0.23 & 0.26 & 0.29 & 0.24 & 0.31 & 0.50 & 0.30 & 0.15 & (1) & ns \\
\hline C16:0 & 10.6 & 9.91 & 9.69 & 12.9 & 10.1 & 8.55 & 10.9 & 8.63 & 9.75 & 10.3 & 9.33 & 8.13 & 13.2 & 10.2 & 12.4 & 1.50 & & ** \\
\hline C16:1 & 0.24 & 0.18 & 0.16 & 0.31 & 0.17 & 0.14 & 0.18 & 0.12 & 0.12 & 0.17 & 0.18 & 0.16 & 0.17 & 0.14 & 0.13 & 0.05 & * & $* * *$ \\
\hline C18:0 & 13.5 & 12.8 & 14.3 & 14.3 & 13.5 & 13.0 & 14.2 & 13.5 & 14.2 & 13.8 & 12.3 & 12.4 & 14.0 & 13.1 & 17.5 & 1.54 & ns & ns \\
\hline C18:1 & 8.37 & 9.51 & 9.64 & 9.35 & 8.03 & 7.54 & 7.99 & 8.07 & 8.86 & 7.23 & 9.17 & 8.58 & 8.26 & 8.34 & 10.8 & 1.16 & ns & ns \\
\hline C18:2n-6 & 6.35 & 7.16 & 7.51 & 7.44 & 6.72 & 6.21 & 6.98 & 6.66 & 7.44 & 6.00 & 6.72 & 6.70 & 11.9 & 6.99 & 9.97 & 0.99 & $* * *$ & ns \\
\hline C18:3n-3 & 0.82 & 0.91 & 0.69 & 0.45 & 0.37 & 0.60 & 0.63 & 0.71 & 0.35 & 0.90 & 0.84 & 0.52 & 1.04 & 0.56 & 0.97 & 0.30 & ns & ns \\
\hline C20:1 & 0.08 & 0.11 & 0.17 & 0.09 & 0.14 & 0.15 & 0.13 & 0.13 & 0.19 & 0.06 & 0.12 & 0.12 & 0.06 & 0.06 & 0.15 & 0.06 & ns & * \\
\hline$C 20: 2$ & 0.11 & 0.16 & 0.17 & 0.13 & 0.11 & 0.13 & 0.09 & 0.11 & 0.17 & 0.10 & 0.11 & 0.17 & 0.27 & 0.14 & 0.26 & 0.05 & ns & ns \\
\hline$C 20: 3 n-6$ & 0.24 & 0.25 & 0.39 & 0.34 & 0.33 & 0.28 & 0.28 & 0.29 & 0.53 & 0.27 & 0.29 & 0.39 & 0.32 & 0.33 & 0.47 & 0.10 & ns & ** \\
\hline$C 20: 4 n-6$ & 8.27 & 6.35 & 5.71 & 7.78 & 6.14 & 4.84 & 5.84 & 5.76 & 5.32 & 5.00 & 3.15 & 3.68 & 8.15 & 6.19 & 7.10 & 0.98 & $* * *$ & $* * *$ \\
\hline$C 20: 5 n-3$ & 0.82 & 1.95 & 3.71 & 1.66 & 2.82 & 3.43 & 3.76 & 2.22 & 3.37 & 3.45 & 3.73 & 4.73 & 0.46 & 2.49 & 4.78 & 0.87 & ns & ** \\
\hline$C 22: 5 n-3$ & 1.04 & 1.19 & 1.50 & 1.33 & 1.17 & 1.06 & 1.48 & 1.19 & 1.47 & 1.53 & 1.47 & 1.31 & 1.45 & 1.13 & 1.61 & 0.22 & ns & ns \\
\hline$C 22: 6 n-3$ & 5.58 & 5.28 & 5.93 & 7.00 & 5.87 & 4.83 & 6.85 & 5.56 & 6.31 & 7.11 & 5.72 & 4.53 & 5.17 & 5.98 & 7.14 & 1.22 & ns & ns \\
\hline SAFA & 24.3 & 23.0 & 24.3 & 27.8 & 15.9 & 21.8 & 25.5 & 22.3 & 24.2 & 16.2 & 21.9 & 20.8 & 27.7 & 23.9 & 30.1 & 5.84 & * & * \\
\hline MUFA & 8.69 & 9.80 & 9.96 & 9.74 & 5.56 & 7.84 & 8.29 & 8.32 & 9.17 & 5.00 & 9.47 & 8.86 & 8.49 & 8.61 & 11.1 & 2.36 & ns & ns \\
\hline PUFA & 23.3 & 23.3 & 25.7 & 26.1 & 15.7 & 21.5 & 25.9 & 22.6 & 25.0 & 16.3 & 22.2 & 22.1 & 28.9 & 23.9 & 32.4 & 5.67 & * & ns \\
\hline Total & 56.3 & 56.1 & 60.0 & 63.6 & 37.2 & 51.1 & 59.7 & 53.2 & 58.4 & 37.5 & 53.6 & 51.8 & 65.0 & 56.3 & 73.6 & 13.2 & 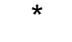 & . \\
\hline$n-6$ & 15.0 & 13.9 & 13.7 & 15.6 & 8.83 & 11.4 & 13.1 & 12.8 & 13.4 & 7.59 & 10.3 & 10.8 & 20.5 & 13.6 & 17.7 & 3.18 & $* * *$ & ns \\
\hline$n-3$ & 8.26 & 9.3 & 11.8 & 10.3 & 6.82 & 9.92 & 12.7 & 9.68 & 11.5 & 8.66 & 11.8 & 11.0 & 8.12 & 10.2 & 14.5 & 3.38 & ns & ns \\
\hline$n-6: n-3$ & 1.82 & 1.59 & 1.16 & 1.51 & 1.30 & 1.19 & 1.23 & 1.32 & 1.77 & 0.97 & 0.88 & 0.99 & 2.64 & 1.35 & 1.22 & 0.23 & * & ** \\
\hline
\end{tabular}

\section{Discussion}

A recent published study (Lauridsen and Danielsen, 2004) showed that depending on the fat source, addition of fat to sows diet at the $8 \%$ level improved the performance of the progeny by increasing the output of fat and energy into the sow milk. As expected, according to the low number of replications in the present study, dietary treatments of the sows had no influence on the performance of the litters. In addition, sow milk fatty acid composition was influenced by the fatty acid composition of the dietary fat sources in a predictable fashion (Lauridsen and Danielsen, 2004), and in accordance with that study, the present results show that the ratio of $n-6: n-3$ fatty acids ranged in the sow milk in the following order: 12.8 (sunflower oil), 8.0 (control), 6.6 (coconut oil), 3.0 (rapeseed oil) and 1.2 (fish oil). In contrast with the former study (Lauridsen and Danielsen, 2004), we did not find an increase in the total fatty acid concentration in sow milk when adding $8 \%$ fat to the diet; however, the design of the experiment was more aimed at revealing differences in the fatty acid composition caused by the sow diet rather than showing differences in total fatty acid content. The present study, which was conducted using the same dietary composition of the experimental sow diets, shows that the fatty acid composition of the sow diet (and the milk) clearly influences the fatty acid composition of the plasma and tissues of the sucking progeny. However, although a high concentration of $\mathrm{C} 12: 0$ (and presence of $\mathrm{C10:0)}$ was measured in the coconut oil diet and in the milk of sows on this treatment, only small amounts of C12:0 (and no detectable C10:0) in plasma and adipose tissue of the piglets were obtained, and not in the liver, thus indicating that these fatty acids to a major extent were oxidised in the body as seen previously in pigs (Straarup et al., 2003). Contrary to the former study (Lauridsen and Danielsen, 2004), sow milk was the only feed provided for the sucking piglets as no creep feed was offered in the present study. Thus, the dietary ratio of $n-6: n-3$ in sows milk markedly influenced the progeny, as the ratio varying from 1.2 (fish oil) to 12.4 (sunflower oil) in the sow milk was highly reflected in the plasma and adipose tissue. Because the pattern of fatty acids in circulation and in adipose tissue was similar to that in the sows' milk, it is unlikely that there was a contribution from lipogenesis in the pig. When considering the adipose tissue, the $n-6: n-3$ ratio of piglets sucking sows fed rapeseed oil or fish oil was similar to the ratio found in sow milk of these treatments, but the $n-6: n-3$ ratio was elevated in the adipose tissue of piglets sucking sows fed control diet, coconut oil and notably sunflower oil, and this was mainly due to the higher proportion of $\mathrm{C} 18: 2$ in the adipose tissue rather than a change in the long-chain $n-6$ fatty acids (C20:4n-6 and C22:5n-6). In accordance with previous studies (e.g. Arbuckle and Innis, 1992), we found that feeding C18:3n-3 by inclusion of rapeseed oil was not as efficient in transferring and depositing long-chain fatty acids of the $n-3$ family compared with the inclusion of fish oil, thus indicating a limited capacity for desaturation and elongation of 
C18:3n-3 by either the sow and/or the piglet as also explained by Rooke et al. (2000). Likewise, the content of C20:4n-6 was not higher in sow milk or piglets of the sunflower group, probably due to a limited biosynthesis from C18:2n-6.

The relative fatty acid composition of the liver was slightly different from the plasma and the adipose tissue, and the lower liver ratio of $n-6: n-3$ fatty acids may indicate the capability of fatty acid metabolism in terms of increased desaturase activity in favour of the $\mathrm{n}-3$ family. Interestingly it was found that irrespective of the dietary treatments, the concentration of $\mathrm{C} 14: 0, \mathrm{C} 16: 0$ and C18:1 in the liver decreased from day 4 to later on during suckling, indicating either an increased liver fatty acid metabolism or a generally lower intake of dietary fatty acids from milk than with colostrum.

The reason for the decrease in total fatty acids, FFA and cholesterol measured in plasma at day 35 compared with day 25 of age may be due to a lower intake of fat in relation to energy when offered the solid feed $v$. the sow milk. In addition, the decrease in triglyceride and vitamin $\mathrm{E}$ concentration may indicate a lower fat-absorption capacity post weaning, e.g. due to the reduced secretion of lipase during the first weeks post weaning (Jensen et al., 1997), and/or decrease in carboxylic ester hydrolase, which has a role in the hydrolysis of the dietary $\alpha$-tocopherol acetate of the weaner feed (Hedemann and Jensen, 1999; Lauridsen et al., 2001). On the other hand, the presence of $\mathrm{C12:0}$ in the adipose tissue post weaning, combined with hepatic fatty acid concentration being in the same range as during suckling, seems to indicate that triaglycerols were not released from fat depots in significant amounts to provide energy. Chwalibog et al. (1994) showed that the potential of post-weaning piglets for growth was so high that fat depots were utilised to support protein accretion and suggested an addition of $8 \%$ fat to the diet to support energy requirement, which was actually covered in the weaner diet used in the present study. Accordingly, some studies have shown that during the post-weaning period, piglets mobilise fat rather than protein (Whittemore et al., 1978), whereby it would be expected in the present study that a major impact of piglet age, rather than dietary sow treatment, on the fatty acid composition post weaning would be observed. On the other hand, since the lipid absorption capacity of the piglets seemed to be reduced post weaning, the 'old pool' of fatty acids from the sow milk could be expected to be present in the liver and adipose tissues during the 1st weeks post weaning, which was actually the case since dietary treatments of the sows also had a major impact on the tissue fatty acid composition after weaning.

Little is known with regard to the fatty acid metabolism of the progeny after weaning from the sow milk. Responses such as plasma FFA and triglyceride were not affected pre- and post weaning by the dietary treatments of the sows, and it seems therefore likely that the lipolysis rate was not influenced by the differing fatty acid composition provided the piglets pre- or post weaning. Because the $n-6: n-3$ ratio of the weaner feed (2.9) was at the approximately same level as observed for the milk of sows fed rapeseed oil (3.0), it was not surprising to observe a general decrease in the $n-6: n-3$ ratio of the liver in the weaned piglets irrespective of the fatty acid source provided with the milk. The overall observations made here demonstrate, however, a reflection of the fatty acid profiles of the maternal dietary fat, even 3 weeks after intake of the sow milk.

The concentration of several fatty acids in liver decreased around weaning (i.e. from day 25 to day 35 of age), but interestingly, the long-chain n-3 fatty acids either did not change (C20:5n-3, C22:5n-3) or even increase (C22:6n-3). However, as shown by Arbuckle and Innis (1992), neonatal piglets offered formula containing C18:3n-3 were capable of synthesising C22:6n-3 and depositing the acid in brain tissue. In the present study, the increase in the liver concentration of C22:6n-3 seems to confirm that the liver of the piglet is capable of elongating and desaturating fatty acids (Clandinin et al., 1985). It has been questioned if C18:2n- 6 and C18:3n-3 can fulfil the total requirements of young infants for assimilation of C20:4n-6 and C22:6n-3 (Innis, 1993). Inadequate maternal $n-3$ fatty acid nutrition has been shown to have adverse effects, such as impaired visual and cognitive development, in the offspring of man and experimental animals (Uauy et al., 2000). In the pig, as in man (Clandinin et al., 1980), brain growth and therefore accretion of $\mathrm{C} 22: 6 \mathrm{n}-3$ is greatest in the last third of pregnancy (Sweasey et al., 1976; Passingham, 1985). Furthermore, the n-3 PUFA found in fish oils have received considerable interests, since they have been shown to exert beneficial health effects (Calder, 1998). Rooke et al. (2000) observed that the progeny of sows offered tuna oil during lactation exhibited a reduced check in growth as a result of weaning, which might be related to the anti-inflammatory properties of the long-chain $n-3$ PUFA. Thus, our observation of an increased or unchanged concentration of C20:5n-3, C22:5n-3 and C22:6n-3 post weaning, and a decrease in the concentration of other fatty acids may indicate their essentiality within the body of young infants.

\section{Conclusion}

The present experiment showed that the dietary fatty acid composition of the maternal diet provided from late gestation and during lactation has a major impact on the composition of fatty acids of the sucking progeny and the influence continued after weaning from the milk. Thus, the ratio of $n-6: n-3$ fatty acids of the maternal diet has a major impact on the ratio of these fatty acids in the body lipids of the progeny pre- and post weaning. Furthermore, addition of fish oil, rather than rapeseed oil, to the maternal diet is an efficient way of providing the progeny with the long-chain n-3 PUFA. 


\section{Acknowledgements}

The authors wish to thank laboratory assistants Winnie $\varnothing$. Thomsen and Elsebeth Lyng Pedersen for their technical assistance.

\section{References}

Aaman P and Hesselman K 1984. Analysis of starch and other constituents of cereal grains. Swedish Journal of Agricultural Research 14, 135-139.

Arbuckle LD and Innis SM 1992. Docosahexanoic acid in developing brain and retina of piglets fed high or low $\alpha$-linoleate formula with and without fish oil. Lipids 27, 89-93.

Association of Official Analytical Chemists 1990. Official method of analysis, 15th edition. AOAC, Arlington, VA, USA.

Bligh EG and Dyer WJ 1959. A rapid method of total lipid extraction and purification. Canadian Journal of Biochemistry and Physiology 37, 911-917.

Boisen S and Fernandez J 1997. Prediction of the total tract digestibility of energy in feedstuffs and pig diets by in vitro analyses. Animal Feed Science and Technology 68, 277-286.

Calder PC 1998. Dietary fatty acids and the immune system. Nutrition Reviews 56, S70-S83.

Cera KR, Mahan DC and Reinhart GA 1988. Weekly digestibilities of diets supplemented with corn oil, lard or tallow by weanling swine. Journal of Animal Science 66, 1430-1437.

Chwalibog A, Jakobsen K and Thorbek G 1994. Loss of body fat in piglets in spite of gain in live weight. Journal of Animal Physiology and Animal Nutrition $72,80-85$.

Clandinin MT, Chappell JE, Leong S, Heim T, Swyer PR and Chance GW 1980. Intrauterine fatty acid accretion rates in human brain: implications for fatty acid requirements. Early Human Development 4, 121-129.

Clandinin MT, Wong K and Hacker RR 1985. Synthesis of chain elongationdesaturation products of linoleic acid by liver and brain microsomes during development of the pig. The Biochemical Journal 226, 303-309.

Cranwell PD and Moughan PJ 1989. Biological limitations imposed by the digestive system to the growth performance of weaned pigs. In Manipulating pig production vol. II (ed. JL Barnett and DP Hennessy), p. 149. Australasian Pig Science Association, Victoria, Australia.

Fossati P and Prencipe L 1982. Serum triglycerides determined colorimetrically with an enzyme that produces hydrogen peroxide. Clinical Chemistry 28, 2077-2080.

Hedemann MS and Jensen SK 1999. Vitamin E in newly weaned piglets is correlated to the activity of carboxyl ester hydrolase, p. 181. APSA, Adelaide, Australia 28 November-1 December (abstract).

Innis SM 1992. Essential fatty acids in growth and development. Progression in Lipid Research 30, 39-103.
Innis SM 1993. Dietary fat quality and infant nutrition. Scandinavian Journal of Nutrition 37, 60-62.

Jensen MS, Gabert VM, Jørgensen H and Engberg RM 1997. Collection of pancreatic juice from growing pigs. International Journal of Pancreatology 21 , 173-188.

Jensen SK, Engberg RM and Hedemann MS 1999. All-rac- $\alpha$-tocopheryl acetate is a better vitamin $\mathrm{E}$ source than all-rac- $\alpha$-tocoperyl succinate for broilers. The Journal of Nutrition 129, 1355-1360.

Lauridsen C and Danielsen V 2004. Lactational dietary fat levels and sources influence milk composition and performance of sows and their progeny. Livestock Production Science 91, 95-105.

Lauridsen C, Hedemann MS and Jensen SK 2001. Hydrolysis of tocopherol and retinyl esters by porcine carboxyl ester hydrolase is affected by their carboxylate and bile acids. The Journal of Nutritional Biochemistry 12, 219-224.

Passingham RE 1985. Rates of brain development in mammals including man. Brain Behavior and Evolution 26, 167-175.

Rooke JA, Shanks M and Edwards SA 2000. Effect of offering maize, linseed or tuna oils throughout pregnancy and lactation on sow and piglet tissue composition and piglet performance. Animal Science 71, 289-299.

Rothenberg $S$ and Andersen JO 1980. The effect of dietary citrus pectin in fatty acid balance and on the fatty acid content of the liver and small intestine in rats. Acta Agriculturae Scandinavica, Section A, Animal Science 30, 8-12.

Simopoulus AP 1986. Summary at the conference on the health effects of polyunsaturated fatty acids in seafoods. The Journal of Nutrition 116, 2350-2354.

Statistical Analysis Systems Institute 1999. SAS version 8.2. SAS Institute, Cary, NC, USA.

Stoldt W 1952. Vorschlag zur Vereinheitlichung der Fettbestimmung in Lebensmitteln. Fette Seifen 54, 206-207.

Straarup EM, Danielsen V, Jakobsen K and Hoy CE 2003. Fat digestibility, nitrogen retention, and fatty acid profiles in blood and tissues of post-weaning piglets fed interesterified fats. Journal of Animal and Feed Sciences 12, 539-559.

Sweasey D, Patterson DSP and Glancy EM 1976. Biphasic myelination and the fatty acid composition of cerebrosides and cholesterol esters in the developing central nervous system of the domestic pig. Journal of Neurochemistry 27, 375-380.

Trinder P 1969. Determination of glucose in blood using glucose oxidase with an alternative oxygen acceptor. Annual Clinical Biological Chemistry 6, 24-27. Uauy R, Mena P and Rojas C 2000. Essential fatty acids: structural and functional role. Proceedings of the Nutrition Society 59, 3-15.

Whittemore CT, Aumaitre A and Williams IH 1978. Growth and body composition in young weaned pigs. Journal of Agricultural Science, Cambridge 91, 681-692. 